Т.Ф. Шмельова ${ }^{1}$, Ю.В. Сікірда ${ }^{2}$, М.В. Касаткін ${ }^{3}$

${ }^{1}$ Національний авіачійний університет, Київ

2 Льотна академія Національного авіаційного університету, Кропивницький

${ }^{3}$ Харківський національний університет Повітряних Сил ім. І. Кожедуба, Харків

\title{
ДЕТЕРМІНОВАНІ ТА НЕДЕТЕРМІНОВАНІ МОДЕЛІ СУМІСНОГО ПРИЙНЯТТЯ РІШЕНЬ ОПЕРАТОРАМИ АЕРОНАВІГАЦІЙНОЇ СИСТЕМИ
}

У статті представлено моделі прийняття сумісних / спільних рішень екіпажем повітряного судна та авіадиспетчером в детермінованих умовах, а також умовах стохастичної та нестохастичної невизначеності. Методологічною основою для спільного прийняття рішень в умовах визначеності є мережеве планування, в умовах стохастичної невизначеності - дерево рішень, в умовах нестохастичної невизначеності матриия рішень. Для інтелектуальної обробки даних та оцінки ризику сумісного прийняття рішень розроблений багатошаровий персептрон з додатковими входами - зсувами, щьо характеризують взаємодію операторів аеронавігаційної системи. Наведено приклади сумісного прийняття рішень в особливому випадку в польоті “Відмова та пожежа двигуна на повітряному судні при наборі висоти після зльоту”.

Ключові слова: багатошаровий персептрон, дерево рішень, матриия рішень, мережеве планування, оптимальна взаємодія, синхронізація прочедур, сценарій розвитку ситуащії.

\section{Вступ}

Постановка проблеми. Як показують дані Aviation Safety Network [1], 2018 рік став одним 3 найбезпечніших років світової комерційної авіації. Протягом 2018 року зафіксовано загалом 15 авіакатастроф (12 катастроф трапилось 3 пасажирськими рейсами, три - 3 вантажними), внаслідок яких загинуло 556 осіб. Це робить 2018 рік третім найбезпечнішим роком за кількістю авіаційних подій (АП) із смертельними наслідками та дев'ятим найбезпечнішим за кількістю загиблих. Але показники безпеки польотів за 2018 рік виявилися гіршими за середньостатистичні за п’ять років (14 авіакатастроф та 480 загиблих) та за самий безпечний в історії авіації 2017 рік 310 катастрофами та 44 загиблими [2]. Зважаючи на світовий повітряний трафік близько 37800000 рейсів за рік, рівень аварійності за 2018 рік складає одну катастрофу на 2520000 рейсів. Починаючи з 1997 року спостерігається стійке зниження середньої кількості авіакатастроф завдяки постійним зусиллям міжнародних авіаційних організацій, спрямованим на підвищення безпеки польотів [2].

У 2018 році в цивільній авіації державучасників міждержавної Угоди про цивільну авіацію та про використання повітряного простору трапилося 58 АП, в тому числі 25 катастроф з загибеллю 164 осіб. У комерційній авіації мали місце 34 АП, в тому числі 15 катастроф, загинули 143 людини. В авіації загального призначення трапилося 24 АП, в тому числі 10 катастроф, загинула 21 людина [3]. За національною належністю повітряних суден АП розподілилися наступним чином:
- Республіка Білорусь - одне АП;

- Республіка Казахстан - шість АП;

- Республіка Молдова - одна катастрофа, загинули 12 осіб;

- Росія - 42 АП, в тому числі 22 катастрофи, загинули 128 осіб;

- Україна - вісім АП, в тому числі дві катастрофи, загинули 24 людини.

3 кожним роком повітряні судна (ПС) стають все більш надійними і безпечними. Але які б зусилля не прикладалися авіаспеціалістами для підвищення безпеки конструкції повітряного судна (ПС), наразі не вдається повністю виключити людський фактор, який є однією $з$ найпоширеніших причин АП. За даними Міждержавного авіаційного комітету, серед причин АП за 2018 рік 80\% займають відхилення в діях авіаційного персоналу при виконанні та організації польотів і лише $20 \%$ - відмови авіаційної техніки [3]. Світова статистика також показує, що основною причиною трагедій в повітрі $є$ людський фактор (помилка екіпажу або диспетчера) [4-6].

Головна роль у підтримці безпеки польотів належить командиру, який здійснює безпосереднє керування ПС та приймає остаточне рішення на всіх етапах польоту і у будь-якій особливій ситуації. Авіадиспетчер несе відповідальність за видачу своєчасних, грамотних і обгрунтованих рекомендацій та вказівок командиру ПС з урахуванням польотної ситуації, повітряної обстановки та метеорологічних умов [7-8].

Ефективна взаємодія “екіпаж ПС - диспетчер" $\epsilon$ обов'язковою умовою для забезпечення безпеки польотів в стандартних умовах та позаштатних си- 
туаціях [8]. Особливу значущість узгодженість дій екіпажу та диспетчера набуває в ситуаціях, які виникають в польоті внаслідок впливу небезпечних факторів - особливих випадках в польоті (ОВП) [9], основними характеристиками яких є гострий дефіцит часу на прийняття рішень, неповнота і невизначеність наявної інформації, а також значне психофізіологічне навантаження на екіпаж ПС.

Різноманітність обставин при кожному ОВП не дозволяє встановити точний детальний порядок дій, якого слід дотримуватися. При роботі в аварійних умовах органи управління повітряним рухом здійснюють повну і всеосяжну координацію дій, а персонал керується здоровим глуздом. Взаємодія між екіпажем ПС та в ОВП полягає в наступному [8]:

- льотний екіпаж у своїх діях керується вимогами керівництва з льотної експлуатації та документів, що регламентують льотну роботу;

- диспетчерський персонал в своїх діях керується технологіями роботи на конкретних робочих місцях 3 урахуванням місцевих умов і особливостей обслуговування повітряного руху, при цьому суворо дотримуючись правил радіообміну з екіпажами ПС, що перебувають під його керуванням, виключивши радіообмін, що не належить до даної ситуації.

Проблема авіадиспетчера в ОВП полягає в неповноті та неточності даних про процес польоту ПС. Проблема екіпажу ПС в ОВП полягає в неповноті і неточності даних про повітряний простір. Зменшити невизначеність та підвищити ефективність взаємодії операторів аеронавігаційної системи (АНС) в ОВП можна шляхом розробки моделей сумісного / спільного прийняття рішень (ПР) операторами в умовах визначеності, ризику та невизначеності.

Аналіз останніх досліджень і публікацій. Глобальний обсяг авіаперевезень подвоюється кожні 15 років, починаючи з 1977 року, і буде збільшуватися такими ж темпами [10]. Тому мета Глобального аеронавігаційного плану полягає в підвищенні пропускної спроможності та ефективності глобальної системи цивільної авіації, в той же час підвищуючи, або, щонайменше, підтримуючи існуючий рівень безпеки польотів [10].

Центральне місце в Глобальній експлуатаційній концепції організації повітряного руху (АТМ) [11] займає питання підвищення взаємодії всіх членів спільноти АТМ (авіакомпаній, постачальників аеронавігаційних послуг, аеропортів, авіаційної влади тощо) шляхом переходу до використання цілісних, кооперативних і сумісних / спільних процесів прийняття рішень (Collaborative Decision Making CDM) з метою досягнення оптимальних результатів на основі рівноправності та забезпечення доступу до інформації.

CDM передбачає безперервний процес представлення інформації та індивідуального ПР різни- ми взаємодіючими учасниками, а також забезпечення синхронізації прийнятих учасниками рішень та обміну інформацією між ними [12]. Важливо забезпечити можливість прийняття сумісного / спільного комплексного рішення партнерами на прийнятному рівні ефективності [11]. Це досягається повнотою і точністю наявної інформації.

Впровадження CDM потребує використання сучасного інформаційного середовища на основі концепції загальносистемного управління інформацією (SWIM - System Wide Information Management) та концепції інформації про політ та потоки повітряного руху для спільного використання повітряного простору (FF-ICE - Flight \& Flow Information for a Collaborative Environment) [12-13].

Динамічний характер АНС обумовлює необхідність ПР, які мають різні часові горизонти. Поняття динамізму означає середовище, в якому подальший розвиток подій одночасно характеризується як невизначеністю, так і викликаною цим мінливістю цілей та рішень. CDM щодо планування польотів в умовах прогнозованого виникнення небезпечних метеоявищ та щодо дій при потраплянні ПС в небезпечні метеоявища потребують різних підходів. Процес CDM повинен діяти по відношенню до рішень всіх рівнів, починаючи від довгострокового планування і закінчуючи технологічними операціями операторів AHC. Для оперативного CDM необхідне попереднє визначення та узгодження відповідних процедур і правил взаємодії [14-15].

Наразі в рамках концепції Airport CDM впроваджуються конкретні рішення, які здатні об'єднати інтереси партнерів (операторів аеропорту, експлуатантів ПС, агентів 3 наземного обслуговування та служби організації повітряного руху) в спільній роботі, створити основи ефективного прийняття рішень завдяки більш точній і своєчасній інформації, що дає всім партнерам в аеропорту єдину оперативну картину повітряного руху [16-17].

В забезпеченні безпеки польотів ключову роль грає можливість організації оперативного CDM між екіпажем та авіадиспетчером на основі діалогу між ними та оцінки інформації в реальному масштабі часу на всіх етапах польоту ПС. Програма "Joint Operational Incidents Training” (“Спільна операційна підготовка до роботи при інциденті”), яка використовується між службою управління повітряним рухом Німеччини та авіакомпанією Люфтганза (JOINT/DFS/DLH) [18], підтвердила, що CDM підвищує ситуаційну усвідомленість операторів АНC (пілота, диспетчера) для створення єдиного образу польоту. Це дозволяє активно слідкувати за повітряною обстановкою, прогнозувати розвиток польотної ситуації та попереджати іiї розвиток у бік погіршення. 
Для підвищення ефективності взаємодії операторів АНС доцільним $є$ комплексне застосування різних підходів до ПР, які розглядаються в рамках інженерної психології, ергономіки, психології і фізіології праці [19-20]. Авіація є однією з прикладних галузей, у яку найбільший внесок зробила психологічна наука. Концепція управління ресурсами екіпажу (CRM) в цивільній авіації вперше була введена Національною адміністрацією з питань аеронавтики та космічного простору (NASA) у 1979 році з метою поліпшення безпеки польотів, спочатку регулюючи принципи взаємодії між членами льотного екіпажу. Сьогодні ця концепція отримала подальший розвиток та стала одним 3 найуспішніших інструментів боротьби з людськими помилками [21-22].

Соціоніка та соціометрика [23-24] пропонують сучасні підходи до вирішення проблем взаємодії в екіпажі ПС та диспетчерській зміні як у малих групах [25-26].

В роботах [19-20] представлено детерміновані, стохастичні, нейромережеві, марковські, GERTмоделі прийняття рішень операторами АНC (пілотом, диспетчером) без врахування взаємодії між ними.

Метою статті $\epsilon$ розробка моделей сумісного ПР екіпажем ПС та авіадиспетчером при виникненні ОВП в умовах визначеності, ризику та невизначеності для оптимальної синхронізації технологічних процедур операторів АНС.

\section{Виклад основного матеріалу}

Сумісне прийняття рішень в умовах визначеності. В умовах визначеності сумісне ПР екіпажем ПС та авіадиспетчером при ОВП доцільно досліджувати шляхом побудови детермінованих моделей за допомогою методів мережевого планування [19-20]. Критичний час на виконання дій авіадиспетчером визначається відповідно до технології дій фахівця з обслуговування повітряного руху з використанням принципів ASSIST (Acknowledge, Separate, Silence, Inform, Support, Time) за “Типовими картами дій фахівців ОПР в аварійних та непередбачуваних ситуаціях" [18], екіпажем ПС - відповідно до керівництва з льотної експлуатації певного типу ПС.

Паралельний процес одночасного виконання технологічних операцій екіпажем ПС та диспетчером в ОВП можна представити у вигляді консолідованої двохканальної мережі. Для послідовної оптимізації подібної мережі з метою досягнення наскрізної ефективності сумісних рішень доцільно використовувати мільтикритеріальній підхід: досягнення мінімального часу на парирування ОВП при максимальній безпеці/максимальному узгодженні за часом дій операторів. Способами оптимізації мережевого графіку виконання технологічних процедур оператором АНС у разі виникнення ОВП (за мінімізацією часу при максимальній безпеці) є [27]:

1. Оптимізація за часом - оптимізація часу виконання процедур критичного шляху $t_{i}^{k}$ за рахунок регулювання використання ресурсів (1):

$$
t_{i}^{k-1}<t_{i}^{k}<t_{i}^{k+1}
$$

де $t_{i}^{k-1}=\max \min t_{i}^{k}-$ мінімальний час при максимальній безпеці;

$$
t_{i}^{k+1}=\min \max t_{i}^{k}-\text { критичний час максима- }
$$

льного (критичного) шляху;

$t_{i}^{k}$ - оптимальний час.

2. Змінення топології мережі за рахунок багатоваріантних технологій виконання процедур.

3. Введення паралельного виконання процедур 3 максимальним узгодженням за часом (оптимальним часом для двох і більше графіків), тобто отримання консолідованого часу на виконання процедур $t_{j}^{k}(2)$ :

$$
t_{j}^{k-1}<t_{j}^{k}<t_{j}^{k+1}
$$

де $t_{j}^{k-1}=\max \min t_{j}^{k}-$ мінімальний час 3 максимальним узгодженням за часом;

$t_{j}^{k+1}=\min \max t_{j}^{k}-$ критичний час максимального (критичного) шляху;

$$
t_{j}^{k} \text { - оптимальний час. }
$$

Побудований мережевий графік виконання процедур екіпажем ПС та диспетчером при виникненні ОВП “Відмова та пожежа двигуна на ПС при наборі висоти після зльоту” (рис. 1).

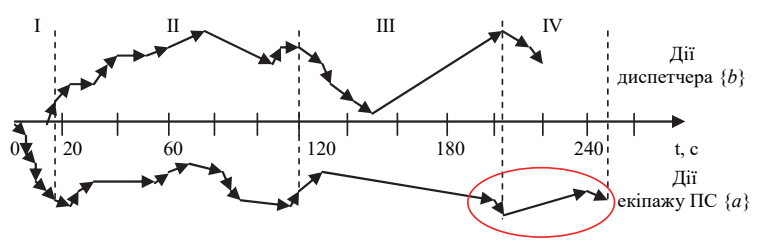

Рис. 1. Мережевий графік виконання процедур екіпажем ПС та диспетчером для прикладу виникнення ОВП "Відмова та пожежа двигуна на ПС при наборі висоти після зльоту”: I етап - відмова двигуна; II етап - пожежа двигуна; III етап - захід на посадку; IV етап - аварійна посадка

Мережевий графік дозволив визначити критичний час залежно від рішення, прийнятого командиром ПС (здійснювати вимушену посадку на аеродромі вильоту з прямим або зворотним курсом), який становить $T_{\text {крит } n p}=6$ хв. $02 \mathrm{c} \mathrm{і} T_{\text {крит } з \text { в }}=4$ хв. $10 \mathrm{c}$ відповідно. Отже, в залежності від умов та обставин, при виникненні таких відмов ПС швидше виконає 
посадку при заході зі зворотним курсом. Таким чином, це оптимальний варіант завершення польоту.

Час, необхідний для виконання дій, спрямованих на парирування ОВП, вимірювався в процесі моделювання на тренажері під час тренування льотних екіпажів та диспетчерів цивільної авіації України, льотчиків та керівників польотів Повітряних Сил Збройних Сил України, а також екіпажів кількох іноземних авіакомпаній.

Сумісне прийняття рішень в умовах стохастичної невизначеності. В умовах стохастичної невизначеності, коли кожна альтернатива $A_{i}$ пов'язана 3 множиною можливих наслідків $u_{j}$, причому кожному наслідку відповідає ймовірність виникнення $p_{j}$, послідовність дій оператора доцільно відображати 3 позицій системного підходу у вигляді дерева рішень [19-20]. Ризик у випадку сумісного ПР операторами АНС в ОВП знаходиться за формулою (3):

$$
\begin{gathered}
R_{m}=F_{m}\left(t_{m} ;\{A\} ;\{\alpha\} ;\{u\} ;\{p\}\right)= \\
=t_{m}\left(\sum_{k=1}^{n} p_{k} u_{k}+\alpha_{k}\right), R_{m} m a(<;>) R_{m-1},
\end{gathered}
$$

де $t$ - час етапу ПР;

$A$ - вимушена посадка 3 прямим / зворотним курсом;

$\alpha-$ зсув ризику розвитку ОВП відповідно до етапу ПР;

$p$ - ймовірність впливу несприятливих факторів;

$u$ - збиток при вимушеній посадці з прямим / зворотним курсом.

Відповідно до дій екіпажу щодо посадки ПС (рис. 1) за допомогою дерева рішень (рис. 2) отримуємо наступні ризики ПР:

$$
\begin{gathered}
R_{3}\left(A_{41}, A_{42}\right)=A_{41}, A_{41}<A_{42}, \\
\text { de } A_{41}=t_{3}\left(p_{411} u_{411}+p_{412} u_{412}\right)+\alpha_{41} ; \\
A_{42}=t_{3}\left(p_{421} u_{421}+p_{422} u_{422}\right)+\alpha_{42} ; \\
R_{2}\left(A_{31}, A_{32}\right)=A_{32}, A_{31}>A_{32}, \\
\text { de } A_{31}=t_{2}\left(p_{311} u_{311}+p_{312} u_{312}\right)+\alpha_{31} ; \\
A_{32}=A_{41}+t_{3}\left(p_{321} u_{321}+p_{322} u_{322}\right)+\alpha_{32} ; \\
R_{1}\left(A_{11}, A_{12}\right)=A_{12}, A_{11}>A_{12}, \\
\text { дe } A_{11}=A_{22}+t_{1}\left(p_{111} u_{111}+p_{112} u_{112}\right)+\alpha_{11} ; \\
A_{12}=A_{32}+t_{1}\left(p_{121} u_{121}+p_{122} u_{122}+p_{123} u_{123}\right)+\alpha_{12} .
\end{gathered}
$$

Розрахунок ризику сумісного ПР екіпажем ПС та диспетчером для прикладу виникнення ОВП “Відмова та пожежа двигуна на ПС при наборі висоти після зльоту” наводиться на рис. 2.

Оптимальна альтернатива знаходиться за критерієм мінімізації ризику (4):

$$
A_{\text {opt }}=\min \left\{R_{m}\right\} \text {. }
$$

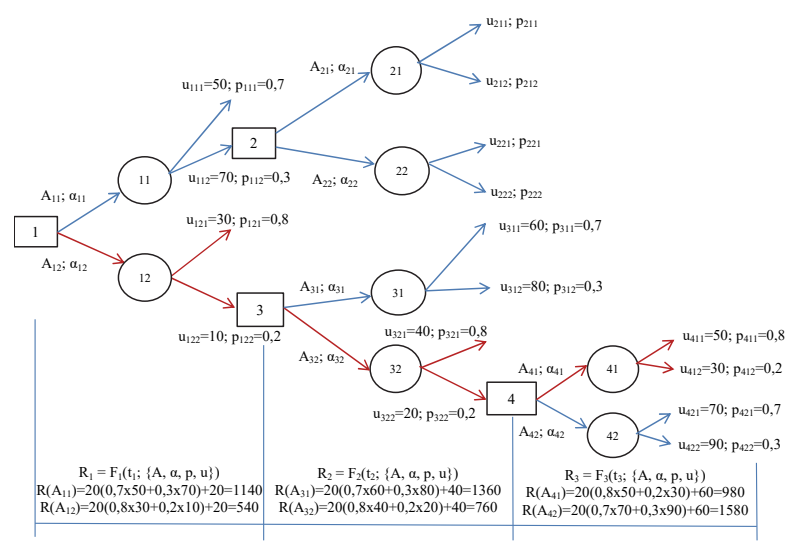

Рис. 2. Дерево рішень для прикладу виникнення ОВП “Відмова та пожежа двигуна на ПС при наборі висоти після зльоту”

Відповідно до матриці показнику ризику ICAO [28], в якій враховуються серйозність та ймовірність можливих наслідків, на основі теорії нечітких множин із застосуванням лінгвістичних змінних визначено шкалу прийнятності (допустимості) ризику [29]: екстремальний ризик (100 балів), високий ризик (80 балів), помірний ризик (60 балів), низький ризик (40 балів) та мізерний ризик (20 балів). Для забезпечення достатнього рівня безпеки польотів показники ризику повинні бути не більше 60 балів, що прийнято за максимально допустиме значення рівня небезпеки.

Сумісне прийняття рішень в умовах нестохастичної невизначеності. В умовах нестохастичної (повної) невизначеності, коли розподіл імовірностей, що відповідає факторам, які впливають на ПР, або невідомий, або не може бути визначений, методологічною основою для сумісного ПР операторами АНС є матриця рішень [19-20]. Приклад альтернативних рішень та матриці витрат в ОВП “Відмова та пожежа двигуна на ПС при наборі висоти після зльоту” наводяться на рис. 3 та в табл. 1.

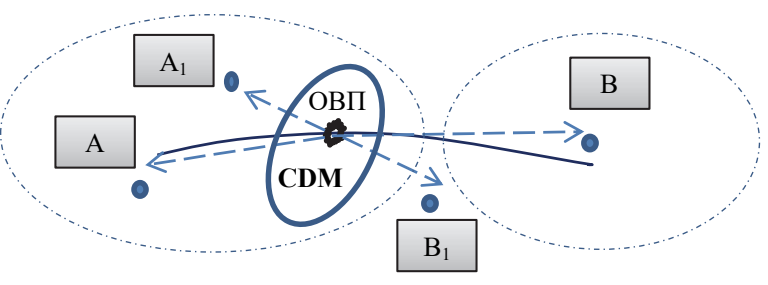

Рис. 3. Альтернативні рішення в ОВП “Відмова та пожежа двигуна на ПС при наборі висоти після зльоту" 
Таблиця 1

Матриця витрат в ОВП “Відмова та пожежа двигуна на ПС при наборі висоти після зльоту”

\begin{tabular}{|c|c|c|c|c|c|c|c|c|c|c|}
\hline & \multicolumn{3}{|c|}{\begin{tabular}{|c} 
Фактори, що \\
впливають \\
на ПР \\
диспетчером, $\lambda_{1}$
\end{tabular}} & \multicolumn{4}{|c|}{$\begin{array}{c}\text { Фактори, } \\
\text { що впливають на ПР } \\
\text { екіпажем ПС, } \lambda_{2}\end{array}$} & \multicolumn{2}{|c|}{ Результати } \\
\hline Аль & ИВ & 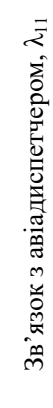 & 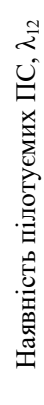 & 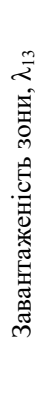 & 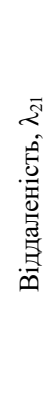 & 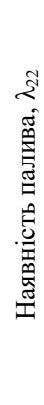 & 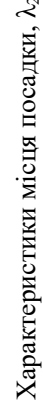 & 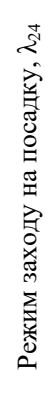 & 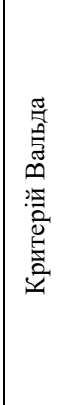 & 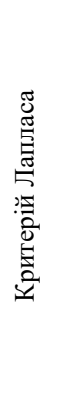 \\
\hline Вимушена & $A$ & 60 & 80 & 70 & 40 & 20 & 30 & 90 & 90 & 55 \\
\hline $\begin{array}{c}\text { посадка зі } \\
\text { зворотним } \\
\text { курсом } A\end{array}$ & $A_{1}$ & 50 & 60 & 50 & 70 & 30 & 40 & 80 & 80 & 55 \\
\hline Вимушена & $B$ & 80 & 70 & 60 & 60 & 40 & 50 & 100 & 100 & 63 \\
\hline $\begin{array}{c}\text { посадка } \\
3 \text { прямим } \\
\text { курсом } B\end{array}$ & $B_{1}$ & 70 & 70 & 70 & 80 & 50 & 60 & 90 & 90 & 70 \\
\hline
\end{tabular}

При використанні критерію Вальда кожна дія оцінюється за найгіршим станом для цієї дії, і “оптимальною” є дія, яка призводить до найкращого 3 найгірших станів. Даний критерій використовує оціночну функцію, що відповідає позиції крайньої обережності (5):

$$
A^{*}=\min _{A_{i}}\left\{\max _{\lambda_{j}} u_{i j}\left(A_{i}, \lambda_{j}\right)\right\},
$$

де $u_{i j}$ - витрати, що відповідають альтернативі $A_{i} \mathrm{i}$ зовнішнім умовам $\lambda_{j}$, які зумовлюють наслідок прийнятого рішення.

$$
\begin{aligned}
& A_{W}{ }^{*}=\min \{\max (60,80,70,40,20,30,90) ; \\
& \max (50,60,50,70,30,40,80) ; \\
& \max (80,70,60,60,40,50,100) ; \\
& \max (70,70,70,80,50,60,90)\}= \\
& =\min \{90 ; 80 ; 100 ; 90\}=A_{1}^{*}=80 .
\end{aligned}
$$

Оптимальне рішення за методом Лапласа, що є критерієм недостатнього обгрунтування, визначається за умови (6):

$$
\begin{aligned}
& A^{*}=\min _{A_{i}}\left\{\frac{1}{m} \sum_{j=1}^{n} u_{i j}\left(A_{i}, \lambda_{j}\right)\right\} . \\
& A_{L} *=\min \{(60,80,70,40,20,30,90) / 7) ; \\
& (50,60,50,70,30,40,80) / 7 ; \\
& (80,70,60,60,40,50,100) / 7 ; \\
& (70,70,70,80,50,60,90) / 7\}= \\
& =\min \{55 ; 55 ; 63 ; 70\}=A^{*}, A_{1}^{*}=55 .
\end{aligned}
$$

Оптимальне рішення за критерієм Вальда (мінімаксним) доцільно застосовувати при нерегулярних польотах, він забезпечує гарантійний результат і повністю виключає ризик. Застосування методу Лапласа доцільне в випадках регулярних польотів, тобто, коли маршрут повністю відпрацьований i ризик мінімальний.

Для моделювання CDM екіпажем ПС та диспетчером в ОВП наступними кроками є глибокий аналіз ОВП; інтелектуальна обробка даних; ідентифікація ситуації; формалізація ситуації за допомогою інтегрованих моделей; декомпозиція комплексної ситуації на підкласи; синтез адаптованих детермінованих моделей для визначення дій штучного інтелекту [30-33].

Інтелектуальна обробка даних при оцінюванні ризику сумісного прийняття рішень за допомогою нейромережевої моделі. Для оцінки ризику сумісного ПР екіпажем ПС та диспетчером в ОВП розроблено багатошаровий прямонаправлений персептрон типу MLP (Multilayer Perceptron Network), який має чотири шари, два з яких сховані (рис. 4).

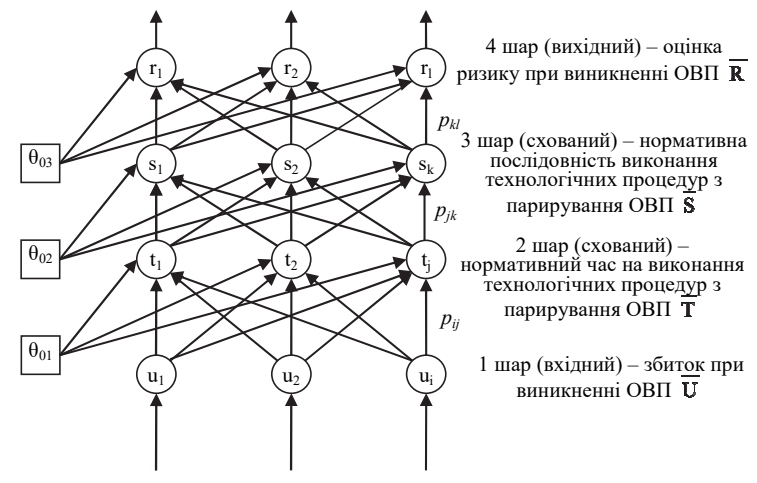

Рис. 4. Багатошаровий персептрон для оцінки ризику при CDM в ОВП

Розглянемо приклад ШНМ:

Перший шар (вхідний) - входи $u_{1}, u_{2}, \ldots, u_{i}$ відповідають збиткам при виникненні ОВП $(\bar{U})$.

Другий шар (схований) - нормативний час на виконання технологічних процедур 3 парирування ОВП $(\bar{T})$ з урахуванням додаткового входу Bias, що характеризує взаємодію операторів АНС. Вихідний вектор другого шару (7):

$$
\bar{T}=f\left(\bar{W}_{1}, \bar{U}\right)=f\left(\overline{n e t}_{1}-\bar{\theta}_{01}\right),
$$

де $\overline{n e t}_{1}=\bar{W}_{1} \bar{U}$;

$\bar{W}_{1}$ - вагові коефіцієнти, що враховують ймовірність порушення нормативного часу на виконання технологічних процедур з парирування ОВП:

$$
\bar{W}_{1}=\left\{t_{i j}\right\} ;
$$


$\bar{\theta}_{01}$ - зсув часу на виконання технологічних процедур 3 парирування ОВП при сумісних узгоджених діях операторів АНС.

Третій шар (схований) - нормативна послідовність виконання технологічних процедур 3 парирування ОВП $(\bar{S})$. Додатковий вхід Вias характеризує взаємодію операторів АНС. Вихідний вектор шару (8):

$$
\bar{S}=f\left(\bar{W}_{2}, \bar{T}\right)=f\left(\overline{\text { net }}_{2}-\bar{\theta}_{02}\right),
$$

де $\overline{\operatorname{net}}_{2}=\bar{W}_{2} \bar{T}$;

$\bar{W}_{2}$ - вагові коефіцієнти, що враховують ймовірність порушення послідовності виконання технологічних процедур з парирування ОВП:

$$
\bar{W}_{2}=\left\{s_{i j}\right\} ;
$$

$\bar{\theta}_{02}$ - зсув часу на виконання технологічних процедур з парирування ОВП при сумісних узгоджених діях операторів АНС.

Четвертий шар (вихідний) - оцінка ризику при виникненні ОВП $(\bar{R})$. Додатковий вхід Bias характеризує складність ОВП. Вихідний вектор шару (9):

$$
\bar{R}=f\left(\bar{W}_{3}, \bar{S}\right)=f\left(\overline{n e t}_{3}-\bar{\theta}_{03}\right),
$$

де $\overline{n e t}_{3}=\bar{W}_{3} \bar{S}$;

$\bar{W}_{3}$ - вагові коефіцієнти, що враховують ймовірність виникнення ускладнень ОВП (наприклад, відмова двигуна може спровокувати пожежу або пошкодження органів керування ПС):

$$
\bar{W}_{3}=\left\{r_{i j}\right\} \text {; }
$$

$\bar{\theta}_{03}$ - зсув часу на виконання технологічних процедур 3 парирування ОВП у разі виникнення його ускладнень при сумісних узгоджених діях операторів АНС.

Задаються наступні вихідні сигнали векторів шарів нейронів $\bar{T}, \bar{S}, \bar{R}(10)$ :

$$
t_{j} S_{k} r_{l}=\left\{\begin{array}{l}
1 ; \text { if } f(x)>0 \\
0 ; \text { if } f(x) \leq 0,
\end{array},\right.
$$

де $f$ - нелінійна функція активації.

За допомогою нейромережевої моделі були отримані значення ймовірностей $(p)$, очікуваних результатів - ризиків $(r)$ та додаткових входів - зсувів $(\theta)$ (рис. 4) при сумісному ПР екіпажем ПС і диспетчером у разі виникнення ОВП [27].

\section{Висновки}

Розроблено детерміновані, стохастичні, нестохастичні та нейромережеві моделі сумісного / спільного ПР екіпажем ПС і диспетчером при виникненні ОВП для оптимальної синхронізації технологічних процедур операторів АНC.

Методологічною основою для спільного ПР в умовах визначеності $\epsilon$ мережеве планування, в умовах стохастичної невизначеності - дерево рішень, в умовах нестахастичної невизначеності - матриця рішень. Для інтелектуальної обробки даних та оцінки ризику сумісного ПР розроблений багатошаровий персептрон 3 додатковими входами - зсувами, що характеризують взаємодію операторів АНС. Наведено приклади сумісного ПР в ОВП “Відмова та пожежа двигуна на ПС при наборі висоти після зльоту".

Напрямком подальших досліджень $є$ інтеграція стохастичних та нестохастичних моделей сумісного ПР операторами АНС для корегування детермінованих моделей на основі апостеріорних даних щодо розвитку ОВП.

Розроблені моделі дозволять доповнити базу сценаріїв розвитку польотних ситуацій в системі підтримки прийняття рішення пілота / диспетчера в ОВП для оптимізації сумісного ПР та можуть бути використані в подальшому як в процесі тренажерної підготовки операторів АНС, так і в реальних умовах експлуатації ПС на основі використання концепцій SWIM та FF-ICE.

\section{Список літератури}

1. Aviation Safety Network. Aviation Safety Network releases 2018 airliner accident statistics [Electronic resource]. - Access mode: https://news.aviation-safety.net/2019/01/01/aviation-safety-network-releases-2018-airliner-accident-statistics/.

2. Aviation Safety Network. ASN data show 2017 was safest year in aviation history [Electronic resource]. - Access mode: https://news.aviation-safety.net/2017/12/30/preliminary-asn-data-show-2017-safest-year-aviation-history/.

3. Состояние безопасности полетов в гражданской авиации государств-участников Соглашения о гражданской авиации и об использовании воздушного пространства в 2018 г. - М.: МАК, 2019. - 107 с.

4. Фориншурер: страхование. Статистика крупнейших авиакатастроф мира 1974-2019 [Электронный ресурс]. - Режим доступа: https://forinsurer.com/public/17/01/10/3824.

5. Human Factors in Aviation. First Edition / Eds. M. Friedman, E. Carterette, E. Wiener, D. Nagel. - USA, Cambridge, Massachusetts: Academic Press, 2014. - 684 p.

6. Human Factors Guidelines for Safety Audits Manual. Doc. 9806-AN/763. First Edition. - Canada, Montreal: ICAO, 2002. $-138 \mathrm{p}$.

7. Наставление по производству полетов в гражданской авиации СССР (с изменениями и дополнениями). - М.: Воздушный транспорт, 1985. - 262 с.

8. Air Traffic Management. Doc. 4444-RAC/501. Fifteenth Edition. - Canada, Montreal: ICAO, 2007. - 425 p. 
9. Правила польотів державної авіації в повітряному просторі України: затв. наказом Міністерства оборони України від 09.12.2015 № 700 // Офіційний вісник України. - 2016. - № 5. - С. 292.

10. Global Air Navigation Plan 2016-2030. Doc. ICAO 9750. Fifth Edition. - Canada, Montreal: ICAO, 2016. - 142 p.

11. Global Air Traffic Management Operational Concept. Doc. 9854. First Edition. - Canada, Montreal: ICAO, 2005. - 82 p.

12. Manual on Collaborative Decision-Making (CDM). Doc. 9971. Second Edition. - Canada, Montreal: ICAO, 2014. $166 \mathrm{p}$.

13. Manual on Flight and Flow Information for a Collaborative Environment (FF-ICE). Doc. 9965. First Edition. - Canada, Montreal: ICAO, 2012. - $140 \mathrm{p}$.

14. Manual on Air Traffic Management System Requirements. Doc 9882. First Edition. - Canada, Montreal: ICAO, 2008. $-72 \mathrm{p}$.

15. Global Performance of the Air Navigation System. Doc. 9883. First Edition. - Canada, Montreal: ICAO, 2009. - 176 p.

16. The Manual Airport CDM Implementation. - Brussels, Belgium: European Organization for the Safety of Air Navigation, 2012. - 359 p.

17. Луговая А.В. Совместное принятие решения о потоках прилета и вылета воздушных судов при организации воздушного движения / А.В. Луговая, А.Е. Коновалов // Научный вестник Московского государственного технического университета гражданской авиации. - 2017. - Т. 20. - № 4. - С. 78-87. https://doi.org/10.26467/2079-0619-2017-20-4-78-87.

18. Guidelines for Controller Training in the Handling of Unusual/Emergency Situations. Second Edition. - Brussels, Belgium: European Organization for the Safety of Air Navigation, 2003. -50 p.

19. Харченко В.П. Прийняття рішень в соціотехнічних системах: монографія / В.П. Харченко, Т.Ф. Шмельова, Ю.В. Сікірда. - К.: Національний авіаційний університет, 2016. - 308 с.

20. Socio-Technical Decision Support in Air Navigation Systems: Emerging Research and Opportunities: manuscript / Eds. T. Shmelova, Yu. Sikirda, N. Rizun, A.-B. M. Salem, Yu. Kovalyov. - USA, Hershey: IGI Global, $2018 .-305$ p. https://doi.org/10.4018/978-1-5225-3108-1.

21. Muñoz-Marrón D. Human Factors in Aviation: CRM (Crew Resource Management) / D. Muñoz-Marrón // Papeles del Psicólogo / Psychologist Papers. - 2018. - Vol. 39(3). - P. 191-199. https://doi.org/10.23923/pap.psicol2018.2870.

22. İnan T.T. The Evoluation of Crew Resource Management Concept in Civil Aviation / T.T. İnan // Journal of Aviation. 2018. - Vol. 2(1). - P. 45-55. https://doi.org/10.30518/jav.409931.

23. Blutner R. Two Qubits for C.G. Jung's Theory of Personality / R. Blutner, E. Hochnadel // Cognitive Systems Research. - 2010. - Vol. 11. - P. 243-259.

24. Cillessen A.S.N. Sociometric Methods / A.S.N. Cillessen // Handbook of Peer Interactions, Relationships, and Group / Eds. K.H. Rubin, W.M. Bukovski, B. Laursen. - London: The Guilford Press, 2009. - P. 82-98.

25. Малишевский А.В. Совершенствование управления и планирования в сфере воздушного транспорта методами соционической селекции авиационного персонала / А.В. Малишевский // Научный вестник Московского государственного технического университета гражданской авиации. Сер. Аэромеханика и прочность. - 2010. - № 1(151). - С. $150-157$.

26. Sikirda Yu. Socionics and Sociometry Diagnosting of Air Navigation System's Operator: Chapter 4 / Yu. Sikirda, T. Shmelova // Socio-Technical Decision Support in Air Navigation Systems: Emerging Research and Opportunities: manuscript / Eds. T. Shmelova, Yu. Sikirda, N. Rizun, A.-B. M. Salem, Yu. Kovalyov. - Hershey, USA: IGI Global, 2018. - P. 70-90. https://doi.org/10.4018/978-1-5225-3108-1.ch004.

27. Kasatkin M. Network Analysis of Collaborative Decision Making by Air Navigation System's Human-Operators during Emergency Cases in Flight / M. Kasatkin, Yu. Sikirda, T. Shmelova // Proceedings of the National Aviation University. - 2019. № 1(78). - C. 22-35.

28. Safety Management Manual (SMM). Doc. 9859-AN 474. Third Edition. - Canada, Montreal: ICAO, 2013. - 300 p.

29. Шмельова Т. Ф. Використання теорії нечітких множин для кількісної оцінки ризиків в аеронавігаційній системі / Т.Ф. Шмельова, І.Л. Якуніна, О.В. Полюхович // Проблеми розвитку глобальної системи зв'язку, навігації, спостереження та організації повітряного руху CNS/ATM: наук.-метод. конф., Київ, 28-30 листопада 2012 р.: тези доповідей. - К.: HAУ, 2012. - C. 68.

30. Predictive analytics with aviation big data / S. Ayhan, J. Pesce, P. Comitz, D. Sweet, S. Bliesner, G. Gerberick // Integrated Communications, Navigation and Surveillance Conference (ICNS): Herndon, Virginia, USA, 22-25 April 2013. 2013. - P. 18.1-18.12.

31. Akerkar R. Analytics on Big Aviation Data: Turning Data into Insights / R. Akerkar // International Journal of Computer Science and Applications. - 2014. - Vol. 11. - P. 116-127.

32. Dolgikh S. Spontaneous Concept Learning with Deep Autoencoder / S. Dolgikh // International Journal of Computational Intelligence Systems. - Vol. 12. - Is. 1. - 2018. - P. 1-12.

33. Grobotek T. Intelligent Steps for the Future / T. Grobotek // Skyway. - 2019. - Autumn / Winter. - P. 42-44.

\section{References}

1. The official site of Aviation Safety Network (2018), Aviation Safety Network releases 2018 airliner accident statistics, available at: https://news.aviation-safety.net/2019/01/01/aviation-safety-network-releases-2018-airliner-accident-statistics/ (accessed 10 September 2019).

2. The official site of Aviation Safety Network (2017), ASN data show 2017 was safest year in aviation history, available at: https://news.aviation-safety.net/2017/12/30/preliminary-asn-data-show-2017-safest-year-aviation-history/ (accessed 27 September 2019). 
3. The interstate aviation committee (2019), "Sostojanye bezopasnosty poletov v ghrazhdanskoj avyacyy ghosudarstvuchastnykov Soghlashenyja o ghrazhdanskoj avyacyy y ob yspoljzovanyy vozdushnogho prostranstva v 2018 g." [Flight Safety Condition in Civil Aviation of the States Parties to the Agreement on Civil Aviation and on the Use of Airspace in 2018], Moscow, Russian Federation, 107 p.

4. Forynshurer: strakhovanye (2020), "Statystyka krupnejshykh avyakatastrof myra 1974-2019" [Statistics of the largest air crashes in the world in 1974-2019], available at: https://forinsurer.com/public/17/01/10/3824/ (accessed 10 October 2019).

5. Friedman, M., Carterette, E., Wiener, E. and Nagel, D. (2014), Human Factors in Aviation, Academic Press, Cambridge, Massachusetts, USA, $684 \mathrm{p}$.

6. ICAO (2002), Human Factors Guidelines for Safety Audits Manual, Doc. 9806-AN/763, 1st ed., Montreal, Canada, 138 p.

7. Air Transport (1985), "Nastavlenie po proizvodstvu poletov v grazhdanskoy aviatsii SSSR (s izmeneniyami i dopolneniyami)" [Manual on the production of flights in the civil aviation of the USSR (with changes)], Moscow, $262 \mathrm{p}$.

8. ICAO (2007), Air Traffic Management, Doc. 4444-RAC/501, 15th ed., Montreal, Canada, 425 p.

9. Official Bulletin of Ukraine (2016), "Pravyla poljotiv derzhavnoji aviaciji v povitrjanomu prostori Ukrajiny: zatv. nakazom Ministerstva oborony Ukrajiny No. 700 vid 09.12.2015" [State Aviation Flight Rules in Ukraine's Airspace: Approved by the order of the Ministry of Defense of Ukraine No. 700 dated 09.12.2015], Kyiv, Ukraine, 292 p.

10. ICAO (2016), Global Air Navigation Plan 2016-2030, Doc. 9750, 5th ed., Montreal, Canada, 142 p.

11. ICAO (2005), Global Air Traffic Management Operational Concept, Doc. 9854, 1st ed., Montreal, Canada, 82 p.

12. ICAO (2014), Manual on Collaborative Decision-Making (CDM), Doc. 9971, 2nd ed., Montreal, Canada, 166 p.

13. ICAO (2012), Manual on Flight and Flow Information for a Collaborative Environment (FF-ICE), Doc. 9965, 1st ed., Montreal, Canada, $140 \mathrm{p}$.

14. ICAO (2008), Manual on Air Traffic Management System Requirements, Doc. 9882, 1st ed., Montreal, Canada, 72 p.

15. ICAO (2009), Global Performance of the Air Navigation System, Doc. 9883, 1st ed., Montreal, Canada, 176 p.

16. European Organization for the Safety of Air Navigation (2012), The Manual Airport CDM Implementation, Brussels, Belgium, 359 p.

17. Lygovaya, A.V. and Konovalov, A.E. (2017), "Sovmestnoye prinyatiye resheniya o potokakh prileta i vyleta vozdushnykh sudov pri organizatsii vozdushnogo dvizheniya" [Joint decision-making on the flows of arrival and departure of aircraft in the organization of air traffic ], Scientific Bulletin of the Moscow State Technical University of Civil Aviation, No. 4, pp. 78-87. https://doi.org/10.26467/2079-0619-2017-20-4-78-87.

18. European Organization for the Safety of Air Navigation (2003), Guidelines for Controller Training in the Handling of Unusual/Emergency Situations, 2nd ed., Brussels, Belgium, 50 p.

19. Kharchenko, V.P., Shmelova, T.F. and Sikirda, Yu.V. (2016), "Pryjnyattya rishen v sociotehnichnykh systemakh: monografiya" [Decision-making in sociotechnical systems: monograph], Natsionalnyi Aviatsiinyi Universytet, Kyiv, 308 p.

20. Shmelova, T., Sikirda, Yu., Rizun, N., Salem, A.-B. M. and Kovalyov, Yu. (2018), Socio-Technical Decision Support in Air Navigation Systems: Emerging Research and Opportunities: manuscript, IGI Global, Hershey, USA, 305 p. https://doi.org/10.4018/978-1-5225-3108-1.

21. Muñoz-Marrón, D. (2018), Human Factors in Aviation: CRM (Crew Resource Management), Papeles del Psicólogo / Psychologist Papers, Vol. 39(3), pp. 191-199. https://doi.org/10.23923/pap.psicol2018.2870.

22. İnan, T.T. (2018), The Evoluation of Crew Resource Management Concept in Civil Aviation, Journal of Aviation, Vol. 2 (1), pp. 45-55. https://doi.org/10.30518/jav.409931.

23. Blutner, R. and Hochnadel, E. (2010), Two Qubits for C.G. Jung's Theory of Personality, Cognitive Systems Research, Vol. 11, pp. 243-259.

24. Cillessen, A.S.N. (2009), Sociometric Methods, Handbook of Peer Interactions, Relationships, and Group, The Guilford Press, London, pp. 82-98.

25. Malyshevskiy, A.V. (2010), "Sovershenstvovanie upravleniya i planirovaniya v sfere vozdushnogo transporta metodami sotsionicheskoy selektsii aviatsionnogo personala" [Improving the management and planning in the field of air transport by means of socionic selection of aviation personnel], Scientific Bulletin of the Moscow State Technical University of Civil Aviation, No. 1(151), pp. 150-157.

26. Sikirda, Yu. (2018), Socionics and Sociometry Diagnosting of Air Navigation System's Operator: Chapter 4, SocioTechnical Decision Support in Air Navigation Systems: Emerging Research and Opportunities: manuscript, IGI Global, Hershey, USA, pp. 70-90. https://doi.org/10.4018/978-1-5225-3108-1.ch004.

27. Kasatkin, M., Sikirda, Yu. and Shmelova, T. (2019), Network Analysis of Collaborative Decision Making by Air Navigation System's Human-Operators during Emergency Cases in Flight, Proceedings of the National Aviation University, No. 1(78), pp. 22-35.

28. ICAO (2013), Safety Management Manual (SMM), Doc. 9859-AN 474, 3rd ed., Montreal, Canada, 300 p.

29. Shmelova, T., Yakynina, I. and Polyhovuch, O. (2012), "Vykorystannya teoriyi nechitkykh mnozhyn dlya kil'kisnoyi otsinky ryzykiv v aeronavihatsiyniy systemi" [Using fuzzy set theory to quantify risks in the air navigation system], Problems With the Development of a Global Communications, Navigation, Surveillance and Air Traffic Organization CNS/ATM, Natsionalnyi Aviatsiinyi Universytet, Kyiv, pp. 68.

30. Ayhan, S., Pesce, J., Comitz, P., Sweet, D., Bliesner, S. and Gerberick, G. (2013), Predictive analytics with aviation big data, Integrated Communications, Navigation and Surveillance Conference (ICNS), Herndon, Virginia, USA, pp. 18.1-18.12.

31. Akerkar, R. (2014), Analytics on Big Aviation Data: Turning Data into Insights, International Journal of Computer Science and Applications, Vol. 11, pp. 116-127. 
32. Dolgikh, S. (2018), Spontaneous Concept Learning with Deep Autoencoder, International Journal of Computational Intelligence Systems, Vol. 12, pp. 1-12.

33. Grobotek, T. (2019), Intelligent Steps for the Future, Skyway, pp. 42-44.

Відомості про авторів:

\section{Шмельова Тетяна Федорівна}

доктор технічних наук доцент

професор Національного авіаційного університету,

Київ, Україна

https://orcid.org/0000-0002-9737-6906

\section{Сікірда Юлія Володимирівна}

кандидат технічних наук доцент

доцент Льотної академії

Національного авіаційного університету,

Кропивницький, Україна

https://orcid.org/0000-0002-7303-0441

\section{Касаткін Микола Володимирович}

начальник навчально-тренувального комплексу

факультету перепідготовки та підвищення кваліфікації авіаційного персоналу Харківського національного університету Повітряних Сил ім. І. Кожедуба,

Миколаїв, Україна

https://orcid.org/0000-0002-2501-1756

\section{Information about the authors:}

Tetiana Shmelova

Doctor of Technical Sciences Associated Professor

Professor of National Aviation University,

Kyiv, Ukraine

https://orcid.org/0000-0002-9737-6906

Yuliya Sikirda

Candidate of Technical Sciences Associated Professor

Senior Lecturer of Flight Academy

of the National Aviation University,

Kropyvnytskyi, Ukraine

https://orcid.org/0000-0002-7303-0441

\author{
Mykola Kasatkin \\ Head of Simulator Department \\ of Faculty of Aviation Personnel Retraining and Advanced \\ Training of Ivan Kozhedub Kharkiv National Air Force \\ University, \\ Mukolaiv, Ukraine \\ https://orcid.org/0000-0002-2501-1756
}

\section{ДЕТЕРМИНИРОВАННЫЕ И НЕДЕТЕРМИНИРОВАННЫЕ МОДЕЛИ СОВМЕСТНОГО ПРИНЯТИЯ РЕШЕНИЙ ОПЕРАТОРАМИ АЭРОНАВИГАЦИОННОЙ СИСТЕМЫ}

Т.Ф. Шмелева, Ю.В. Сикирда, Н.В. Касаткин

В статье представлены модели принятия совместных / общих решений экипажем воздушного судна и авиадиспетчером в детерминированных условиях, а также условиях стохастической и нестохастической неопределенности. Методологической основой для совместного принятия решений в условиях определенности является сетевое планирование, в условиях стохастической неопределенности - дерево решений, в условиях нестохастической неопределенности - матрица решений. Для интеллектуальной обработки данных и оценки риска совместного принятия решений разработан многослойный персептрон с дополнительными входами - сдвигами, характеризующими взаимодействие операторов аэронавигачионной системы. Приведены примеры совместного принятия решений в особом случае в полете “Отказ и пожар двигателя на воздушном судне при наборе высоты после взлета".

Ключевые слова: дерево решений, матрииа решений, многослойный персептрон, оптимальное взаимодействие, сетевое планирование, синхронизация процедур, сценарий развития ситуации.

\section{DETERMINATED AND NON-DERMINATED MODELS OF THE COLLABORATIVE DECISION MAKING BY OPERATORS OF THE AIR NAVIGATION SYSTEM}

T. Shmelova, Yu. Sikirda, M. Kasatkin

In this article the models of the Collaborative Decision Making (CDM) by flight crew and air traffic controller in deterministic, stochastic and non-stochastic uncertainty conditions are presented. Effective interaction of the "flight crew - air traffic controller" is a prerequisite for ensuring flight safety in standard conditions and during emergency cases. The problem of air traffic controllers in emergency situations is the incompleteness and inaccuracy of aircraft flight process data. The problem of the flight crew in emergency situations is the incompleteness and inaccuracy of the airspace data. CDM implementation requires the use of a modern information environment based on the System Wide Information Management (SWIM) concept and FF-ICE (Flight \& Flow Information for a Collaborative Environment). The methodological basis for CDM in the conditions of certainty is a network planning. Ways to optimize the network planning for the implementation of technological procedures by the ANS operator in emergency case (minimizing time at maximum security) is to optimize time, change the network topology due to multivariate technology execution procedures, the introduction of parallel procedure execution with maximum time coordination. The methodological basis for CDM in the conditions of stochastic uncertainty - is a decision tree, in the conditions of nonstochastic uncertainty - is a matrix of decisions. For intelligent data processing and risk assessment of CDM, Multilayer Perceptron Network with the additional inputs - Bias, that characterizing the interaction of the Air Navigation Systems' operators, is developed. Examples of CDM in flight emergency "Engine failure and fire on aircraft during climbing after take-off" are given. The developed models will allow to supplement the base of scenarios of flight situations development in the pilot - air traffic controller decision support system during emergency cases for CDM optimization and can be used in the future both in the operators training course and in real aircraft flight.

Keywords: decision matrix, decision tree, multilayer perceptron, network planning, optimal interaction, procedure synchronization, scenario of situation development. 